\title{
Willingness to pay and preference for imported rice brands in Nigeria: Do price- quality differentials explain consumers' inertia?
}

\begin{tabular}{|c|c|}
\hline \multicolumn{2}{|c|}{$\begin{array}{l}\text { Authors: } \\
\text { Uchenna Obih }{ }^{1} \text { (1) } \\
\text { Lloyd S. Baiyegunhi }{ }^{1}\end{array}$} \\
\hline \multicolumn{2}{|c|}{$\begin{array}{l}\text { Affiliations: } \\
{ }^{1} \text { Discipline of Agricultural } \\
\text { Economics, School of } \\
\text { Agricultural, Earth and } \\
\text { Environmental Sciences, } \\
\text { University of KwaZulu-Natal, } \\
\text { South Africa }\end{array}$} \\
\hline \multicolumn{2}{|c|}{$\begin{array}{l}\text { Corresponding author: } \\
\text { Uchenna Obih, } \\
\text { obih_uchenna@yahoo.com }\end{array}$} \\
\hline \multicolumn{2}{|c|}{$\begin{array}{l}\text { Dates: } \\
\text { Received: } 26 \text { Nov. } 2016 \\
\text { Accepted: } 10 \text { Aug. } 2017 \\
\text { Published: } 06 \text { Dec. } 2017\end{array}$} \\
\hline \multicolumn{2}{|c|}{$\begin{array}{l}\text { How to cite this article: } \\
\text { Obih, U. \& Baiyegunhi, L.S., } \\
2017, \text { 'Willingness to pay and } \\
\text { preference for imported rice } \\
\text { brands in Nigeria: Do price- } \\
\text { quality differentials explain } \\
\text { consumers' inertia?', South } \\
\text { African Journal of Economic } \\
\text { and Management Sciences } \\
20(1) \text {, a1710. https://doi. } \\
\text { org/10.4102/sajems. } \\
\text { v20i1.1710 }\end{array}$} \\
\hline \multicolumn{2}{|c|}{$\begin{array}{l}\text { Copyright: } \\
\text { ( } 2017 \text {. The Authors. } \\
\text { Licensee: AOSIS. This wo } \\
\text { is licensed under the } \\
\text { Creative Commons } \\
\text { Attribution License. }\end{array}$} \\
\hline \multicolumn{2}{|l|}{ Read online: } \\
\hline 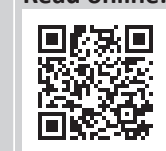 & $\begin{array}{l}\text { Scan this QR } \\
\text { code with your } \\
\text { smart phone or } \\
\text { mobile device } \\
\text { to read online. }\end{array}$ \\
\hline
\end{tabular}

Background: Rice (Oryza sativa) is the most consumed staple food in Nigeria. Consumers have persistently preferred and are willing to pay higher prices for imported rice despite improvements in the quality attributes of local rice brands in the last 5 years. Nigeria's import bill of over \$6million daily on rice is not only a drain on the country's Forex reserves, but a threat to the development of the domestic rice industry. Previous studies on rice consumers' behaviours have not explained the underlying reason of how consumers with imported brands preference mind-set make purchasing decisions when faced with both local and imported rice brands with almost similar quality attributes but different market prices.

Aim: When making purchase decisions, consumers consider product quality in comparison to its price. This study attempts to explain how the differences in prices and quality attributes of local and imported rice brands determine consumer's inertia against preference for imported rice brands in Nigeria.

Setting: This study was conducted in the Federal Capital Territory of Nigeria using data sets collected from a survey of 460 rice consumer households.

Methods: Data were collected using a structured questionnaire administered to the household heads during the face-to-face interview. Two separate binary logit regression models were estimated for households' preference and WTP for imported rice.

Results: The results show that price, household head's age, household's income and general perception are statistically significant variables explaining household's preference and WTP for imported rice brands. Consumers' inertia against preference and WTP for imported rice persists because of the negative price-quality differential gaps between local and imported rice brands.

Conclusion: Rice consumers in Nigeria compare price and quality differentials before making a choice between local and imported rice brands. There is need for implementation of flexible and synergic import restriction and strategic marketing policies that sustain wide price differentials between local and imported rice brands, while improving the quality image of the local brands to narrow consumer's perception of the quality differential between these two sets of brands.

\section{Introduction}

The rice industry plays an important role in Nigeria's economy; this is because rice (Oryza sativa) is the most consumed staple food both in urban and rural households. According to Johnson et al. (2013), about $85 \%$ of households consume rice, spending an average of $6 \%$ of its total income on rice consumption, the highest among all staples consumed in Nigeria. The per capita rice consumption is estimated at $35 \mathrm{~kg}$ per annum, giving a total of 5.2 million metric tons of milled rice consumed in Nigeria per annum (Gyimah-Brempong et al. 2012). The country's domestic rice production, which is estimated at 3 million metric tons per annum, gives a consumption gap of about 2.2 million metric tons per annum, which is being filled by imports (Johnson et al. 2013). Nigeria is among the top five rice importing countries in the world. Past governments had acknowledged that high import bills of over \$6million daily (Johnson et al. 2013) were not only a drain on foreign exchange earnings but also a threat to the growth of the domestic rice industry. In the last 7 years, the government has put in place some programmes and policies to discourage rice importation and encourage domestic production. These included: (1) an increased import tariff on rice from $5 \%$ to $50 \%$ in 2012 and $100 \%$ in 2013 , (2) a ban on importation of rice through the land borders and (3) an establishment of Commercial Agricultural Credit Scheme (CACS) to 
provide cheap funds to agribusinesses, and the Nigeria Incentive-based Risk Sharing System for Agricultural Lending (NIRSAL) programme to encourage commercial banks' lending to the agricultural sector on risk sharing basis. These policies and programmes have so far attracted many investors, leading to massive and expanded investments in paddy rice production and establishment of many modern rice-processing mills. Domestic rice production has been stimulated and has been on the increase annually by more than 5\% (Seck et al. 2010). In the last 5 years, rice production, processing, polishing and packaging in Nigeria have tremendously improved and there are many local rice brands with improved quality attributes (AfricaRice 2012)

Despite improvements in the physio-chemical quality attributes of local rice, there is still a steady increase in the quantity of imported rice consumed in Nigeria because of the burgeoning population, increased consumer incomes, changes in tastes and preferences, rapid urbanisation, ease of preparation that fits easily into urban lifestyle of workers and better physical attributes (Erhabor \& Ojogho 2011). Consumers still prefer imported rice brands based on their already established perception that imported rice brands possess better after-cook physical attributes such as a brightwhite colour and separate, neat and even long grains. (Adeyeye et al. 2010; Johnson et al. 2013; Lancon et al. 2003). According to Erenstein et al. (2003), the fundamental cause of this preference for imported rice is the intrinsic nature and pedigree of the paddy grain found in Nigeria. The visual presentation (a factor that matters the foremost in valuation of rice by the market) of rice milled from such a paddy grain does not match up to its imported kin in terms of grain shape, neatness, colour and percentage of broken rice. Thus, the local consumer applies a rather heavy differential to the price of locally milled rice vis-à-vis imported rice (Lançon \& Benz 2007). This differential can be above N2000 (about $\$ 15)^{1}$ per $50 \mathrm{~kg}$ bag of rice (Erenstein et al. 2003). The long-term negative perception against local rice has become a persistent habit that is strongly responsible for consumers' inertia against preference and willingness to pay (WTP) higher prices for imported rice brands in order to avoid local rice (Akaeze 2010).

Previous studies on rice consumption in Nigeria have been limited to explaining quality differentials as the reason for consumers' preference for imported rice brands (Adeyeye et al. 2010; Alfred \& Adekayode 2014; Bamidele, Abayomi \& Esther 2010; Gyimah-Brempong et al. 2012; Johnson et al. 2013; Kassali et al. 2010; PROPCOM 2007). However, several studies have found that, when making purchase decisions, consumers do not consider product quality in isolation, but in comparison to its price (Akdeniz, Calantone \& Voorhees 2013; Bornemann \& Homburg 2011; Sahay \& Sharma 2010; Thanasuta \& Metharom 2015). It therefore seems that previous studies have not adequately explained the underlying reason on how consumers with a brand preference mindset make purchasing decisions when faced with two or 1.(USD1 = 120 in 2003). more brands of food products with almost similar quality attributes but different market prices. This has left a knowledge gap in consumer behaviour literature, which this study aims to fill by determining how consumers' comparative analyses of price and quality differentials of local and imported rice brands influence their choice behaviour. This is with a view to providing some insight useful for rice marketing managers and government in designing appropriate marketing policy measures for breaking the current consumers' inertia against preference for imported rice brands. Specifically, this study seeks to:

- determine the factors influencing consumer's preference for imported rice brands and provide empirical evidence of this choice behaviour

- assess how market price and consumers' perceived quality differentials determine consumers' inertia against preference for imported rice brands in Nigeria

\section{Theoretical and conceptual framework}

The choice behaviour of consumers towards food products is based on the theoretical framework of Millock et al. (2002). According to this framework, a consumer's purchase behaviour towards food product is a relationship between the consumer's WTP premium price and the market price of the product. Product price is determined by the market, while consumer's WTP is determined by consumer's socio-economic characteristics, consumer's attitude and/or intention and perception of the product's quality attributes (Millock 2002).

Past studies such as Zeng and Wei (2005) and Bonti-Ankomah and Yiridoe (2006) have adopted Millock's framework to explain consumer's behaviour towards food products. The major limitation of this framework is that it explains consumer behaviour from the viewpoint of one product. It answers consumer's typical question of whether a product's quality is worth its market price. However, in real market situations, a consumer is often faced with choice decisions on which brand to buy among two or more alternative brands of similar products with almost the same quality attributes but varying market prices (Chern \& Chang 2009; Zeithaml 1988). For this study, it is assumed that, at the point of purchase, a rational consumer often makes a quick comparative analysis of the differences in the prices and quality attributes of two or more brands of a product before deciding the particular brand to buy. This comparison could be the underlying reason for the consumer's choice behaviour. Therefore, this study was built on the framework developed by Millock et al. (2002). The modified Millock's framework presented in Figure 1 indicates that consumer's choice of a brand of food product from two or more alternative brands is dependent on the price-quality differentials of these alternative brands of the product.

This study also gleaned from literature that consumer's purchasing choice decisions are based on price-quality 


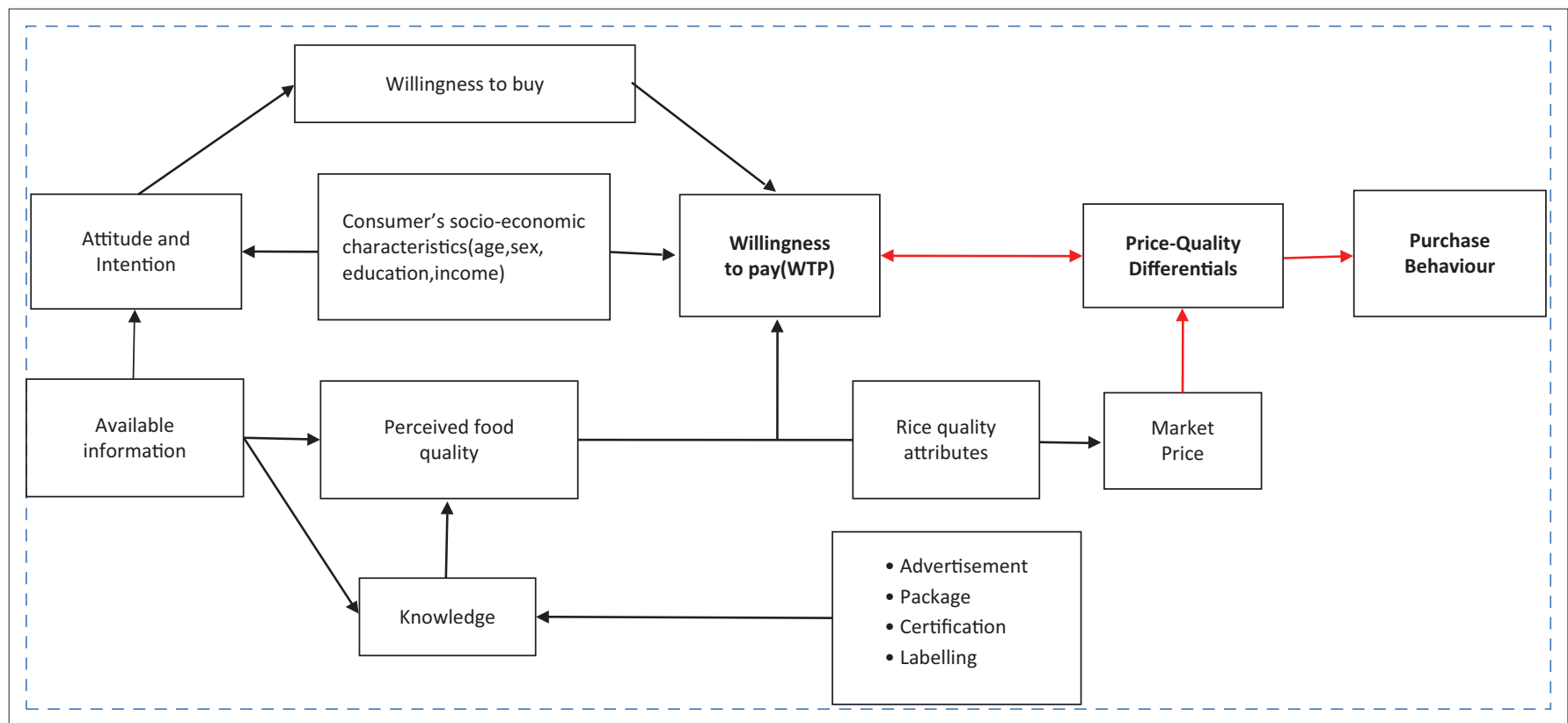

Source: Adapted and modified from Millock, K., Hansen, L.G., Wier, M. \& Anderson, L.M., 2002, 'Willingness to pay for organic foods: A comparison between survey and panel data from Denmark', paper presented at the 2nd World Congress of Environmental and Resource Economists held at Mariott Hotel in Monterey, CA. June 24-27, 2002. http://www.econweb.ucsd.edu/ carsonvs/ papers/5065.pd

FIGURE 1: Conceptual framework for consumer's behaviour towards local and imported rice brands in Nigeria.

relationships (Akdeniz et al. 2013; Bernués, Olaizola \& Corcoran 2003; Gerstner 1985; Krutulyte et al. 2009; Monroe 2003; Shiraia 2015; Thanasuta \& Metharom 2015). Consumer's perception of product's quality has often been estimated by determining consumer's WTP price for the product (Chern \& Chang 2009). The value of WTP often creates a gap between consumer's perceived quality and the market price of the product (Zeithaml 1988). WTP largely reflects the product's quality as perceived by the consumer, while market price largely reflects the product's quality from the producer's perspective (Zeithaml 1988). Previous studies have included market price as explanatory variable in determining consumer's utility and hence WTP (Chern \& Chang 2009; Hanemann 1984). WTP is the additional price consumers pay to reflect preference for a particular brand of a product in order to avoid another brand (Chern \& Chang 2009). Therefore, comparing the differences between the market prices and consumer's perceived qualities could provide some insights on how consumers make decisions when choosing from alternative brands of a product (Hanemann 1984).

For this study, it is assumed that a consumer household is faced with two brands of rice (local and imported rice brands) from which a purchasing choice decision is made by comparing the differences in the market prices of these two brands with the differences in the household's WTP. The Millock framework provides the basis for the choice of explanatory variables upon which this study estimated consumer's preference and WTP using the basic concept of random utility modelling (RUM) by Greene (1974), McFadden (1987) and Haab and McConnell (2002). Random utility modelling is an econometric approach based on the utility theory, which states that, among a set of $J$ number of alternative products, a rational consumer will prefer the alternative $j$ that provides the highest utility $U_{j}$ (Greene 1974;
McFadden 1987). Random utility modelling allows for the parameterisation of the probability of preferring alternative $j$ among $J$ alternatives. The conceptual framework for RUM is based on Lancaster (1966), which assumes that the utility ${ }_{V}$ ) a consumer derives from a product can be decomposed into two components, namely: deterministic component (U), which is observable and often associated with the product price; and random error component $(\varepsilon)$, which represents the unobservable characteristics affecting the consumer's choice. Thus, faced with local and imported rice brands, and assuming a linear representation, the utility function of $i$ th consumer household for alternative choice of a rice brand $j$ can be represented as:

$V_{i j}=U_{i j}+\varepsilon_{i j}$

[Eqn 1]

The utility derived from any of the two alternative rice brands depends on the quality attributes $(U)$ of such a brand (as reflected in the brand's price), consumer household's socio-economic characteristics and general perception of the brand's quality affecting households' decision. A consumer household facing two alternative rice brands chooses the brand associated with higher utility (Hensher, Rose \& Greene 2005). If $\mathrm{Vj}$ and $\mathrm{Vk}$ denote the utility a consumer household derives from consuming imported and local rice brands $j$ and $k$, respectively, and if imported rice is associated with higher utility, then $\mathrm{Vj}>\mathrm{Vk}$. If Yi denotes the $i$ th consumer household's preference for imported rice, then:

$$
\begin{aligned}
& Y_{i}=\left(V_{j}>V_{k}\right)=\left(U_{i j}+\varepsilon_{i j}\right)>\left(U_{i k}+\varepsilon_{i k}\right) \\
& =U_{i j}-U_{i k}>\varepsilon_{i k}-\varepsilon_{i j}=U_{i j}>\varepsilon_{i j} \text { for all } j \neq k
\end{aligned}
$$

The presence of the error component $\varepsilon_{\mathrm{ij}}$ in Equation 2 implies that predicting $i$ th consumer household's preference for 
imported rice cannot be made with certainty. Therefore, the consumer household's behaviour becomes one of probabilistic choices. Hence, the probability that $i$ th consumer household will choose imported rice over the local rice is whether the difference in the deterministic components of their utilities exceeds the difference in the error components (McFadden 1980), and this can be expressed as:

$$
P_{r}\left(Y_{i}=1\right)=U_{i j}-U_{i k}>\varepsilon_{i k}-\varepsilon_{i j}=U_{i j}>\varepsilon_{i j} .
$$

Equation (3) implies that the distribution of the error term, $\varepsilon_{\mathrm{ij}}$ determines the explicit distribution of this probability.

According to McFadden (1980) and Ben-Akiva and Lerman (1985), a typical assumption is that the error term $\varepsilon_{\mathrm{ij}}$ is independently and identically distributed with a type I extreme value distribution specified as follows:

$$
F\left(\varepsilon_{i j}\right)=\exp \left[-\exp \left(-\varepsilon_{i j}\right)\right]
$$

where $F$ denotes the cumulative distribution function and the error term $\varepsilon_{\mathrm{ij}}$ is normally distributed with zero mean and constant variance $\sigma^{2}$. The distribution of the error term $\varepsilon_{\mathrm{ij}}$ as shown in Equation 4 implies that the probability of $i$ th consumer household choosing imported rice $j$ is expressed in terms of the logistic distribution (McFadden 1980) as follows:

$$
\operatorname{Pr}\left(Y_{i j}=1\right)=\frac{\exp ^{U_{i j}}}{1+\exp ^{U_{i j}}},
$$

where

$$
U_{i j}=\beta_{0}+\beta_{i} X_{i} \text { and }-\infty<U_{i j}<+\infty
$$

Equation 6 is a binary equation of $i$ th consumer household choosing imported rice $j ; X_{i}$ is a vector of explanatory variables that influence $i$ th household's purchase decisions such as price, a reflection of quality attributes (Bornemann \& Homburg 2011), household's socio-economic characteristics and general perception of quality attributes of imported rice brands; $\beta_{\mathrm{i}}$ is the vector of estimated coefficients of all the explanatory variables and exp is the base of natural logarithms. The error term is assumed to follow logistic distribution; hence, Equation 5 is the standard binary logit model (Ben-Akiva \& Lerman 1985; Maddala 1993). This discrete choice model is estimated by maximum likelihood technique, and is useful for modelling choice behaviour.

The results of the binary logit model are interpreted in terms of the odds ratios, that is, the ratios of the probability of choosing one outcome category over the reference category. These ratios are defined as:

$L_{n}\left(\frac{P_{i j}}{P_{i k}}\right)=X_{i}\left(\beta_{j}-\beta_{k}=X_{i} \beta_{j}\right.$ if $k=1$ and $L n$ is natural logarithm, [Eqn 7]

where $P_{i k}$ is the probability of $i$ th household choosing local rice. A positive parameter indicates that the relative

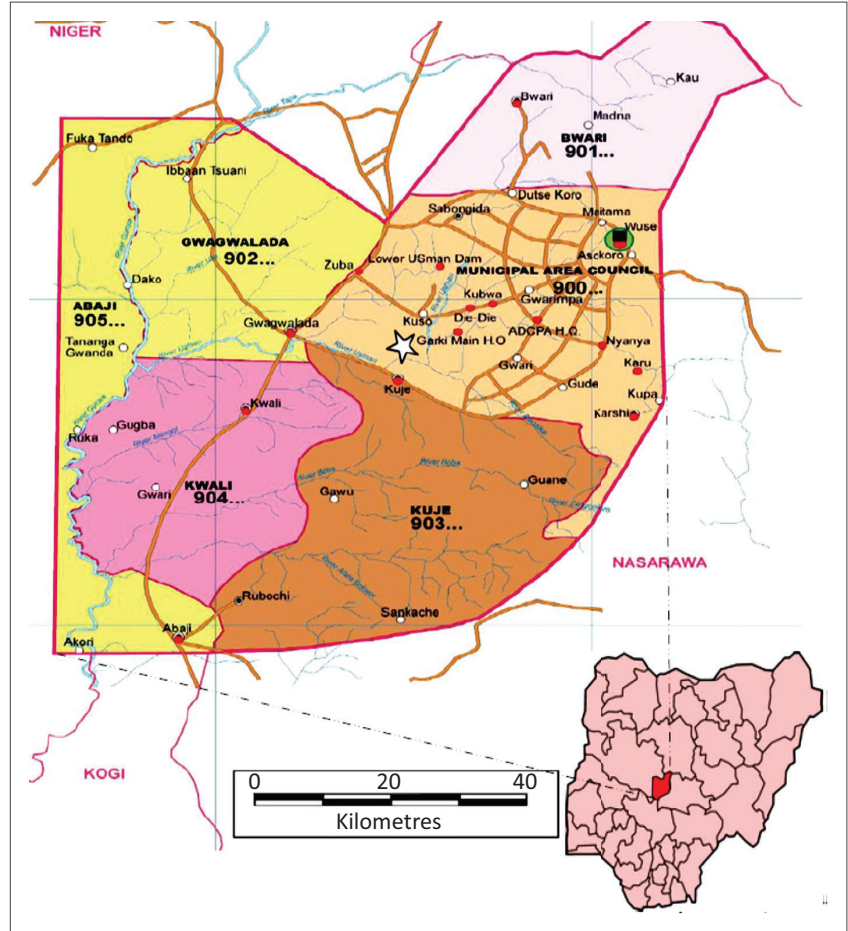

Source: AGIS, 2014, AGIS deploys high resolution satellite imagery of the FCT, Abuja Geographic Information System, viewed from http://agis.fcta.gov.ng/

FIGURE 2: Map of Nigeria showing the Federal Capital Territory and the six area councils surveyed.

probability of $i$ th consumer household choosing imported rice over the local rice increases relative to the probability of choosing local rice over the imported rice; and otherwise for a negative parameter. Following Latvala (2010), if $\operatorname{Pr}\left(Y_{i j}=1\right)$ $>0.5$, there is consumer preference for imported rice brands; and otherwise if $\operatorname{Pr}\left(Y_{i j}=1\right) \leq 0.5$.

\section{Methodology Study area and data}

This study was conducted in the Federal Capital Territory (FCT) located in North Central Nigeria (Figure 2). It lies within latitudes $725^{\prime}$ and $925^{\prime} \mathrm{N}$ and longitude $545^{\prime}$ and 7 $39^{\prime} \mathrm{E}$. It is geographically located in the savannah vegetation and at the centre of the country with a landmass of $7315 \mathrm{~km}^{2}$. Federal Capital Territory is characterised by alternating dry and wet seasons with a mean annual rainfall that varies from $1100 \mathrm{~mm}$ to $1600 \mathrm{~mm}$ and temperatures of between $12^{\circ} \mathrm{C}$ and $33^{\circ} \mathrm{C}$. The FCT has six area councils, namely Abuja Municipal Area Council (AMAC), Bwari, Gwagwalada, Kwali, Kuje and Abaji. AMAC is the area council where the seat of federal government, its agencies and diplomatic offices are located. It has the highest infrastructural development and is residence to politicians, wealthy Nigerians and diplomats. The other area councils are satellite towns with lesser infrastructural development and resident to mostly civil servants, farmers, artisans and traders. The choice of FCT for this study is purposive because it has multi-class consumers of different socio-economic characteristics who have varying demand strength and consumption behaviours. Virtually all imported and local rice brands can be found in the major markets in these area councils. 
Federal Capital Territory has a total population of about 3.5 million people (NPC 2013) out of which at least 70\% (2.45 million people) are rice consumers who constitute our target population of about 490000 households (based on average of five people per household). Following the method used by Yamane (1967), this household population gives a sample size of 400 households which is considered adequate for interview and data collection. To cover wider geographical area of the FCT-Abuja, a multi-stage random sampling method was used in selecting a total of 460respondent households as follows: AMAC (76), ${ }^{2}$ Kuje (77), Gwagwalada (77), Abaji (77), Kwali (76) and Bwari (77). Sampling frames were obtained from the Federal Capital Development Authority (FCDA) and Abuja Geographical Information System (AGIS 2014).

Data were collected using a structured and validated questionnaire. Jury's method was used to test questionnaire content validity (Wallace et al. 2003), while the test-retest method was used to evaluate questionnaire reliability. The questionnaire was primarily administered to the household heads during the face-to-face interview, while other household members contributed in providing answers to the questions raised during the interviews. Data were collected on the consumer households' socio-economic characteristics, level of perception of the quality attributes, market prices at which they buy and maximum prices they are willing to pay for imported rice brands.

\section{Empirical framework for the study}

Many studies have used various methods such as choice experiments and contingent (Goldberg \& Roosen 2005), stated choice experiment (Travisi \& Nijkamp 2004), conjoint analysis (Ara 2003), survey rankings and ratings (Quagrainie 2006), travel cost (Gonzalez \& Loomis 2006), experimental auction method (Yue, Alfnes \& Jensen 2009) and discrete choice modelling (Haab \& McConnell 2002) to estimate WTP as a measure of monetary value of quality attributes of food products as perceived by consumers. Value perception can be defined as a judgement or a valuation by the consumer of the comparison between the benefits or utility obtained from a product, and the perceived sacrifices or costs (Zeithaml 1988). The price consumers are willing to pay for each quality attribute reflects the level of utility derived and the relative importance attached (Sonata \& Rasa 2010). The higher the level of a desirable attribute in an alternative food product, the higher the utility associated with that alternative and more likely the consumer is willing to pay a higher price for it (Bennet \& Blamey 2001).

Assuming the market price $P_{i j}$ that $i$ th consumer pays for imported rice $j$ rises to a new price level $P_{\text {imax' }}$ and if the consumer is willing to pay this price increase in order to keep deriving the same level of utility $U_{i j}$ as previously, the linear utility functions for imported rice at the market price $P_{i j}$ and at higher price $P_{i \max }$ are expressed in Equation 8 and 9 as follows: 2.Values in parentheses denote the number of households interviewed in the area council surveyed.
$U_{i j}=\beta_{0 j}+\beta_{1} P_{i j}+\beta_{2 j} X_{i}+\varepsilon_{i j}$

[Eqn 8]

$U_{i j}=\beta_{0 j}+\beta_{1} P_{i \max }+\beta_{2 j} X_{i}+\varepsilon_{2 i j}$,

[Eqn 9]

$\beta_{0 j}+\beta_{1} P_{i j}+\beta_{2 j} X_{i}+\varepsilon_{i j}=\beta_{0 j}+\beta_{1}\left(P_{i j}+W T P_{i j}\right)+\beta_{2 j} X_{i}+\varepsilon_{2 i j}$, [Eqn 10]

where $P_{i \max }=\left(P_{i j}+W T P_{i j}\right)$ and is the maximum price that $i$ th household can pay for imported rice.

As not all of the $\beta_{0 j}$ s and $\beta_{2 j}$ s are identifiable, and Equation 8 and 9 provide the household with the same level of utility, so normalisation rule was adopted such that $\beta_{0 j} \mathrm{~s}$ and $\beta_{2 j} \mathrm{~s}$ in Equation 8 become equal to zero (Chern \& Chang 2009; Greene 2000). Solving Equation 10 for $W T P_{i j}$ gives:

$W T P_{i j}=\frac{\beta_{0 j}+\beta_{2 j} X_{i}+\left(\varepsilon_{i j}-\varepsilon_{2 i j}\right)}{\beta_{1}}$.

[Eqn 11]

Taking the expected value of the $W T P_{i j}$, the expected WTP higher price for imported rice in order to remain at the same level of utility and avoid local rice is expressed as:

$$
E\left(W T P_{i j} \mid X_{i}\right)=\frac{\beta_{0 j}+\beta_{2 j} X_{i}}{\beta_{1}},
$$

where $W T P_{i j}$ is $i$ th household WTP for increase in the price of imported rice, $X_{i}$ is a vector of explanatory variables that influence $i$ th household's purchase decisions, $\beta_{2 j}$ is the vector of estimated coefficients of all the explanatory variables and $\beta_{1}$ is the coefficient of $P_{i \max }$. Following the same procedure in Equation 5, the probability that $i$ th consumer household is willing to pay a higher price $P_{\text {imax }}$ for imported rice $j$ in order to remain at the same level of utility $U_{i j}$ can be expressed in terms of the logistic distribution (McFadden 1980) as follows:

$$
\operatorname{Pr}\left(W T P_{i j}=1\right)=\frac{\exp ^{U_{i j}}}{1+\exp ^{U_{i j}}},
$$

where

$U_{i j}=\beta_{0}+\beta_{i} X_{i}$ and $-\infty<U_{i j}<+\infty . \quad[$ Eqn 14]

All the explanatory variables $X_{i}$ remain as previously defined except that the market price $P_{i j}$ is replaced with $P_{i \max }$ in Equation 14. Following Latvala (2010), the deciding rule is that: if $\operatorname{Pr}\left(W T P_{i j}=1\right)>0.5$, there is consumer preference for imported rice brands; and otherwise if $\operatorname{Pr}\left(W T P_{i j}=1\right) \leq 0.5$.

\section{Explanatory variables included in the model}

The explanatory variables hypothesised to explain consumers' preference and WTP premium price for imported rice brands were identified based on the theoretical framework and on past empirical work on consumer behaviour towards food products (Bonti-Ankomah \& Yiridoe 2006; Millock et al. 2002; Zeng \& Wei 2005). The explanatory variables are classified into three categories: 
price, household socio-economic characteristics and the strength of consumer's general perception of the quality attributes of imported rice such as neatness, duration of cooking, after-cook colour, aroma, taste, grain shape, swelling capacity, stickiness and texture. The definitions for the variables used in the analysis are presented in Table 1.

\section{Results and discussion Household socio-economic characteristics}

The socio-economic characteristics of the respondent households are presented in Table 2. About $65 \%$ of the respondents are female; this is not unexpected, because women take most purchasing and dietary decisions and generally tend to have more knowledge and bargaining power for food items as compared to men. The average age of household heads is 47 years, while the average number of years spent in formal schooling is 16 years, indicating that household heads are relatively young and educated, with an average household size of five people. Younger and educated households are more likely to prefer and adopt urban lifestyles and food items that are easy to prepare (such as imported rice) than older and less-educated households. The average monthly income of a household head is $\$ 88350$ (about \$441), indicating that households live on an average of about $\$ 10$ per day, which is well above the national monthly minimum wage of 18000 (about \$90). This is because most household heads in the study area are senior private and public employees of government, corporate organisations, international agencies, politicians and top businessmen earning higher wages and income.

\section{Distribution of households according to preferences and willingness to pay for imported rice}

Generally, consumers in Nigeria classify rice as 'local' and 'imported'. The distribution of households by their preference and WTP for imported rice brands in the study area is presented in Table 3.

In all the six study areas, 95\% of the consumer households expressed preference for imported rice as the brand of choice, while $52 \%$ of the households are willing to pay higher price for imported rice brands. Preference for imported rice brands is highest (97\%) in AMAC, Kuje and Gwagwalada, which are locations nearest to the city centre, Abuja. While 93\% and $94 \%$ of respondents in Abaji and Bwari, respectively, also indicated preferences for imported rice. WTP is highest among $50 \%$ of households in Kuje but lowest (38\%) among households in AMAC. The above descriptive analysis shows that people residing in urban areas with high infrastructural development, population density, income level and economic activities are more likely to express higher preference for food products they perceived to possess better quality attributes such as neatness, easy to prepare, lower cooking duration, and so on. This is also an indication that the preference and WTP for imported rice brands is higher in urban areas and cities where the consumers have the ability to pay higher prices for food items they perceive as being of superior quality. Given the higher population growth in semi-urban and rural areas, it is likely that consumer inertia against preference for imported rice brands could be broken in the future when the population of consumers in cities and urban areas becomes lower than the population of consumers in semi-urban and rural areas.

\section{Binary logistic regression results of determinants of household preference and willingness to pay for rice}

The results of the two separate binary logistic regression models estimated for consumer's preference and WTP for imported rice brands are presented in Table 4 .

Both models gave correct predictions of $80 \%$ and $96 \%$ of households' preference and WTP for imported rice,

TABLE 1: Definitions and measure of variables included in the model.

\begin{tabular}{|c|c|c|c|c|c|}
\hline Variable & Category of variables & Specific variables & Definition & Measure & Expected sign $\dagger$ \\
\hline \multirow[t]{2}{*}{$\begin{array}{l}\text { Dependent } \\
\text { variables }\end{array}$} & - & Preference & $\begin{array}{l}\text { Is consumer currently buying imported rice at a price } \\
\text { higher than the market price of local rice? }\end{array}$ & $\begin{array}{l}\text { Yes }=1 \\
\text { No }=0\end{array}$ & $\mathrm{n} / \mathrm{a}$ \\
\hline & - & WTP & $\begin{array}{l}\text { Is consumer willing to pay if the price of imported } \\
\text { rice is raised above its current market price? }\end{array}$ & $\begin{array}{l}\text { Yes }=1 \\
\text { No }=0\end{array}$ & $\mathrm{n} / \mathrm{a}$ \\
\hline \multirow[t]{9}{*}{$\begin{array}{l}\text { Explanatory } \\
\text { variables }\end{array}$} & \multirow[t]{2}{*}{ Price } & $P_{i j}$ & $\begin{array}{l}\text { Retail market price of imported rice } j \text { paid by ith } \\
\text { household }\end{array}$ & Per 50kg bag (in Naira) & + \\
\hline & & $P_{i \max }$ & $\begin{array}{l}\text { Maximum price that ith household agrees it can pay } \\
\text { for imported rice brands }\end{array}$ & Per $50 k g$ bag (in Naira) & + \\
\hline & \multirow{6}{*}{$\begin{array}{l}\text { Socio-economic } \\
\text { characteristics }\end{array}$} & Age & How old the household head is. & Number of years & $+/-$ \\
\hline & & Gender & Sex of the household head. & $\begin{array}{l}\text { Male }=0 \\
\text { Female }=1\end{array}$ & $+/-$ \\
\hline & & Education & Level of formal training received by household head. & Number of years spent in school & $+/-$ \\
\hline & & Income & Level of earnings of household head. & Monthly salary or income (in Naira) & + \\
\hline & & Household size & $\begin{array}{l}\text { Number of people living and feeding together in } \\
\text { same house. }\end{array}$ & Number of people & $+/-$ \\
\hline & & Marital status & Marital state of household head. & $\begin{array}{l}\text { Single }=1 \\
\text { Married }=2 \\
\text { Divorced }=3\end{array}$ & $+/-$ \\
\hline & \multicolumn{2}{|l|}{ Household perception } & $\begin{array}{l}\text { This is a categorical variable that defines consumer's } \\
\text { general level of perception about quality attributes } \\
\text { of imported rice brands. }\end{array}$ & $\begin{array}{l}\text { Strong }=3 \\
\text { Moderate }=2 \\
\text { Weak }=1\end{array}$ & + \\
\hline
\end{tabular}

$\dagger$, Based on a priori expectations.

$\mathrm{n} / \mathrm{a}$, not applicable; $P_{i j}$, Retail market price of imported rice $\mathrm{j}$ paid by ith household; $P_{i \max ,}$, Maximum price that ith household agrees it can pay for imported rice brands 
respectively. Also, in the two models estimated, the Nagelkerke's $R^{2}$ are 0.56 and 0.62 ; the Hosmer and Lemeshow $(H-L)$ tests show significance values greater than 0.05 , while

TABLE 2: Socio-economic characteristics of the sampled households.

\begin{tabular}{|c|c|c|c|c|}
\hline Characteristics & Category & $\begin{array}{l}\text { No. of } \\
\text { respondents }\end{array}$ & Percentage & Mean \\
\hline \multirow[t]{2}{*}{ Gender } & Male & 163 & 35.4 & \multirow[t]{2}{*}{$\mathrm{n} / \mathrm{a}$} \\
\hline & Female & 297 & 64.6 & \\
\hline \multirow[t]{4}{*}{ Age (years) } & $25-35$ & 20 & 4.30 & \multirow[t]{4}{*}{47.27} \\
\hline & $36-46$ & 72 & 15.4 & \\
\hline & $47-57$ & 223 & 48.5 & \\
\hline & $58-68$ & 145 & 31.5 & \\
\hline \multirow{4}{*}{$\begin{array}{l}\text { Education level } \\
\text { (number of years } \\
\text { spent in formal } \\
\text { schooling) }\end{array}$} & $1-6\}$ primary & 74 & 16.2 & \multirow[t]{4}{*}{15.78} \\
\hline & $7-12\}$ secondary & 82 & 17.8 & \\
\hline & $13-18\}$ tertiary & 267 & 58.0 & \\
\hline & $19-24\}$ postgraduate & 37 & 8.00 & \\
\hline \multirow[t]{3}{*}{ Marital status } & Single & 31 & 6.70 & \multirow[t]{3}{*}{-} \\
\hline & Married & 427 & 92.80 & \\
\hline & Divorced & 2 & 0.50 & \\
\hline \multirow[t]{3}{*}{ Household size } & $2-4$ & 119 & 25.90 & \multirow[t]{3}{*}{4.87} \\
\hline & $5-7$ & 268 & 58.30 & \\
\hline & $8-10$ & 73 & 15.80 & \\
\hline \multirow{4}{*}{$\begin{array}{l}\text { Household monthly } \\
\left.\text { income ( } N^{\prime} 000\right)\end{array}$} & $20-120$ & 260 & 56.5 & \multirow[t]{4}{*}{ A88 350} \\
\hline & $121-221$ & 128 & 27.8 & \\
\hline & $222-322$ & 54 & 11.7 & \\
\hline & $323-423$ & 18 & 3.9 & \\
\hline
\end{tabular}

n/a, not applicable; $\#$, Naira (Nigeria's currency)

TABLE 3: Percentage distribution of households by their preference and willingness to pay for imported rice.

\begin{tabular}{lccccc}
\hline Area & \multicolumn{2}{c}{ Preference } & & \multicolumn{3}{c}{ WTP } \\
\cline { 2 - 3 } \cline { 5 - 6 } & Yes & No & & Yes & No \\
\hline AMAC & 97 & 3 & & 38 & 62 \\
Abaji & 93 & 7 & & 55 & 45 \\
Kwali & 95 & 5 & & 53 & 47 \\
Gwagwalada & 97 & 3 & & 51 & 49 \\
Kuje & 97 & 3 & & 58 & 42 \\
Bwari & 94 & 6 & & 57 & 43 \\
Pooled average & 95.5 & 5 & & 52 & 48 \\
\hline
\end{tabular}

AMAC, Abuja Municipal Area Council; WTP, willingness to pay. the chi-square tests of 2 Log Likelihood are significant at 1\%. These indicate that there is no significant difference between observed and model-predicted values, implying a moderately strong relationship between the predictors and the prediction. Therefore, the two estimated binary models provide quite good fits and strong explanatory power. In this study, there is absence of multi-collinearity in the two estimated models because the variance inflation factors (VIFs) for all the variables included in the two models were less than 10 (Menard 1995).

The coefficients of parameter estimates of the binary logit model only provide the direction of the effect of the independent variables on the dependent (response) variable and do not represent the actual magnitude of change or probabilities. Therefore, the marginal effects from the binary model, which measures the expected change in probability of a choice being made with respect to a unit change in the independent variable, are reported as the $\exp (\beta)$ in Table 4. Estimated coefficients for households' choice of imported rice brands are compared with local rice as the base reference choice.

The estimated coefficient for household head's age is positively and statistically significant for the probability of higher household WTP prices for imported rice brands, implying that an increase in the age of household heads is more likely to influence the household to choose imported rice brands over local rice. The marginal effects suggest that a year increase in the age of the household head is likely to increase his or her choice of imported rice brands by $9.9 \%$ relative to local rice. The reason could be that the older the household head is, the more likely he or she has over the years developed stronger negative perception on poorquality attributes of local rice, and has built his or her taste around imported rice brands. This is consistent with the findings of Akaeze (2010) that consumption of imported rice

TABLE 4: Parameter estimates and marginal effects from binary logit model of household preference and willingness to pay for imported rice.

\begin{tabular}{|c|c|c|c|c|c|c|}
\hline \multirow[t]{3}{*}{ Variables } & \multicolumn{3}{|c|}{ Preference } & \multicolumn{3}{|c|}{ WTP } \\
\hline & \multicolumn{2}{|c|}{$\beta$} & \multirow[t]{2}{*}{$\operatorname{Exp}(\beta)$} & \multicolumn{2}{|c|}{$\beta$} & \multirow[t]{2}{*}{$\operatorname{Exp}(\beta)$} \\
\hline & Coefficient & Standard error & & Coefficient & Standard error & \\
\hline Price & 0.001 & $0.0001 \dagger$ & 0.00001 & 0.005 & $0.001 \uparrow$ & 1.005 \\
\hline Gender & -0.180 & 0.271 & 0.835 & 0.509 & 0.667 & 1.664 \\
\hline Age & 0.025 & 0.016 & 1.026 & 0.095 & $0.043 \%$ & 1.099 \\
\hline Education & 0.012 & 0.031 & 1.012 & 0.022 & 0.075 & 1.022 \\
\hline Income & 0.0001 & 0.0001 & 1.000 & 0.0003 & $0.0001 \S$ & 1.000 \\
\hline Household size & 0.017 & 0.084 & 1.017 & 0.268 & 0.202 & 1.308 \\
\hline Marital status & 1.061 & 0.501 & 1.292 & 1.027 & 1.822 & 2.793 \\
\hline Household perception & 1.061 & $0.163 \dagger$ & 1.889 & 0.852 & $0.390 \%$ & 1.345 \\
\hline Constant & -15.719 & $1.995 \dagger$ & - & -49.097 & $11.407 \dagger$ & 0.00001 \\
\hline Number of observations & - & - & 460 & - & - & 460 \\
\hline-2 Log Likelihood & - & - & $248.873 \dagger$ & - & - & $94.656 \dagger$ \\
\hline Nagelkerke $R^{2}$ & - & - & 0.56 & - & - & 0.62 \\
\hline VIF & - & - & 2.272 & - & - & 2.631 \\
\hline Correctly predicted & - & - & $80 \%$ & - & - & $96 \%$ \\
\hline
\end{tabular}

$\dagger$, Denotes statistically significant at the $1 \%$ probability level; $\$$, denotes statistically significant at the $5 \%$ probability level; $\S$, denotes statistically significant at the $10 \%$ probability level. WTP, willingness to pay; VIF, variance inflation factor; $\beta$, Beta; -2 Log Likelihood, a statistical test to compare the two models; Nagelkerke $R^{2}$, a measure of the model's goodness of fit; $\mathrm{H}-\mathrm{L}$ test, Hosmer-Lemeshow test is a statistical test for goodness of fit for logistic regression models 
brands is more of a mindset and habitual persistence. Campbell et al. (2009) suggested that consumer's negative attitude (a mindset) against local rice is stronger among older people who, in the past 1-2 decades, have had bad experience such as the presence of chaffs, impurities, uneven grains, long cooking duration and so on, in consuming local rice.

The estimated coefficient for household income is positive and statistically significant for the probability of household's WTP higher prices for imported rice brands. This implies that an increase in household income increases the probability of household's WTP for imported rice brands. However, the marginal effect suggests that an increase in income is not likely to influence a household's WTP for imported rice brands over the local rice. A possible explanation is that a household may prefer imported rice to local rice but may not be willing to spend additional portion of her income to pay for any increase in the price of imported rice brands. This may indicate increasing consumers' acceptability and competitiveness of local rice in the market. This is consistent in part with a recent study by Alfred and Adekayode (2014) who found that a large percentage of Nigerians consume local rice. Some of the socio-economic variables describing the respondents, such as gender, household size, education and marital status included in the binary logistic model, were not statistically significant for influencing consumer's preference and WTP higher prices for imported rice brands. According to Enneking (2004), this non-significance of socioeconomic characteristics is a typical phenomenon in studies focused on consumer choice.

The estimated coefficient for price is positive and statistically significant for the probability of household's preference and WTP for higher price for imported rice brands. This implies that an increase in the price of imported rice is likely to increase the probability of household's preference and WTP a higher price for imported rice. This is because higher prices often lead to higher quality perceptions (Raghubir \& Corfman 1999). The marginal effect suggests that an increase in market price increases the odds of surveyed household's preference and WTP higher price for imported rice brands over the local rice by $0.001 \%$ and $0.05 \%$ respectively. A possible reason could be household's belief that increased prices of imported rice brands reflect improved quality, and this belief is being reinforced by the perception that imported rice brands have always had better quality attributes than local rice brands.
This supports previous finding of Shiraia (2015) whose appeal leads to favourable price perceptions and purchase intentions when the product price is high. Also, previous report by Campbell et al. (2009) shows that consumers tend to set minimum-quality standards and are unlikely to shift from imported rice to local rice just because the price of the former has risen, instead they tend to shift to lower quality but cheaper imported rice.

The estimated coefficient for consumer household's general perception is positive and statistically significant for the probability of household's preference and WTP for imported rice brands. This implies that an increase in the household's general perception of quality of imported rice is likely to increase the probability of household's preference and WTP for imported rice. The marginal effect suggests that an increase in household's general perception from moderate to strong increases the odds of surveyed household's preference and WTP for imported rice brands over the local rice by $188.9 \%$ and $134.5 \%$, respectively. This indicates that consumer's perception of the quality attributes of food product could be the highest determinant of consumer's preference and WTP (Akaeze 2010; Thanasuta \& Metharom 2015). This could be because households' general perception reflects the total importance attached to the quality attributes of the food product (Chiliya, Herbst \& Roberts-Lombard 2009; Raghubir \& Corfman 1999).

\section{Estimating consumers' preference and willingness to pay for imported rice brands}

In this study, consumers' preferences and WTP increased prices for imported rice brands were determined by estimating their respective probabilities relative to local rice and the results across the six locations surveyed are as shown in Table 5.

Table 5 shows that probabilities of household's preference and WTP for imported rice brands vary across the six locations surveyed. The results show that, on average, the probability that a household prefers imported rice brands over the local rice is $95.6 \%$, while the probability that a household does not prefer imported rice brands over the local rice is $4.6 \%$. Similarly, the probability that a household is willing to pay increased price for imported rice brands in order to avoid the local rice is $75.8 \%$, while the probability

TABLE 5: Estimated probabilities of household's behaviour towards imported rice brands.

\begin{tabular}{|c|c|c|c|c|c|c|c|c|}
\hline \multirow{2}{*}{$\begin{array}{l}\text { Household } \\
\text { behaviour }\end{array}$} & \multirow{2}{*}{$\begin{array}{l}\text { Probabilities of } \\
\text { preference and WTP }\end{array}$} & \multicolumn{7}{|c|}{ Location (area council) } \\
\hline & & AMAC & Abaji & Kwali & Gwagwalada & Kuje & Bwari & $\mathrm{Pr}_{\text {overall }}$ \\
\hline \multirow[t]{3}{*}{ Preference } & $\operatorname{Pr}_{\text {wtpmean }}(Y=1)<0.5$ & 0.036 & 0.062 & 0.026 & 0.070 & 0.051 & 0.029 & 0.046 \\
\hline & $\operatorname{Pr}_{\text {wtpmean }}(Y=1)>0.5$ & 0.964 & 0.938 & 0.985 & 0.930 & 0.949 & 0.971 & 0.956 \\
\hline & $\operatorname{Pr}_{\text {overallmean }}(Y=1)$ & 0.509 & 0.444 & 0.452 & 0.479 & 0.512 & 0.458 & \\
\hline \multirow[t]{3}{*}{ WTP } & $\operatorname{Pr}_{\text {pmean }}(Y=1)<0.5$ & 0.288 & 0.217 & 0.222 & 0.225 & 0.292 & 0.209 & 0.242 \\
\hline & $\operatorname{Pr}_{\text {pmean }}(Y=1)>0.5$ & 0.712 & 0.783 & 0.778 & 0.775 & 0.707 & 0.791 & 0.758 \\
\hline & $\operatorname{Pr}_{\text {overallmean }}(Y=1)$ & 0.673 & 0.627 & 0.652 & 0.675 & 0.708 & 0.668 & \\
\hline
\end{tabular}

Note: $\operatorname{Pr}(Y=1)$ is the mean probability of household's preference of imported rice over the local rice, $\operatorname{Pr} \quad(Y=1)$ is the mean probability of household's WTP for imported rice over the local rice and $\mathrm{Pr}$ Prean $\quad(Y=1)$ is the overall mean probability across the six locations or within each location.

AMAC, Abuja Municipal Area Council; WTP, willingness to pay; $\operatorname{Pr}_{\text {wtpmear' }}$ mean probability of household's WTP; $\operatorname{Pr}$ variable, preference or WTP for imported rice 
that a household is not willing to pay increased price for imported rice brands in order to avoid the local rice is $24.2 \%$. The overall implication is that, while many households may prefer imported rice brands over the local rice, few may actually be willing to pay increased price on imported rice brands in order to avoid local rice. This is consistent with the theory of demand in which higher price leads to lower demand. It also agrees with a recent study by Alfred and Adekayode (2014) whose findings show that large percentage of Nigerians were indifferent in their preference of local and imported rice brands. This is an indication that consumers are beginning to accept local rice as a perfect substitute for imported rice brands.

\section{Consumers' inertia against preference and willingness to pay for imported rice brands}

In this study, consumers' inertia against preference and WTP for imported rice brands is measured by the difference between price and quality differentials of local and imported rice brands as presented in Table 6. The marginal willingness to pay (MWTP) is a measure of the monetary value of a household's WTP based on its perception of the difference in the quality attributes of local and imported rice brands.

The results in Table 6 revealed that, with higher negative price-quality differential gaps, consumers' inertia against preference and WTP for imported rice brands is stronger among households residing in the more developed locations (AMAC, Gwagwalada and Kuje) with proximity to Abuja, the FCT city centre. Consumer households residing in locations such as Bwari, Kwali and Abaji that are further away from the city centre and with lower economic activities seem not to see the market price differential as a true reflection of quality differential between local and imported rice brands. Generally, there is negative pricequality differential gap between local and imported rice brands, and this could be a possible reason for the persistence of consumers' inertia against preference and WTP for imported rice brands in Nigeria. This differential gap of $\$ 396$ (US\$2) per $50 \mathrm{~kg}$ bag that is lower than $\$ 2000$ (US\$15) found by Erestein et al. (2003) indicates a possible growth in consumers' acceptability and competitiveness of local rice in Nigeria as earlier found by Alfred and Adekayode (2014).

\section{Conclusions and implications}

The results emanating from this study have shown that age and income of household heads are important determinants of consumer preference and WTP for imported rice brands. Older household heads, especially those who earn higher incomes, still perceived imported rice as superior to local rice in terms of quality. They would therefore still prefer and be willing to pay the increased price of imported rice because they can afford it. This study also confirmed that the market price and consumer's perception of food quality play a vital role in influencing consumers' choice of rice. Consumer households perceive higher prices of imported rice brands as a reflection of better quality attributes, and this perception reinforces their preference and WTP for imported rice brands. Therefore, there is a need for simultaneous implementations of import restriction policies (such as high import tariffs, levies, duties and taxes to raise the market prices of imported rice brands) and domestic marketing policies that promote a positive image of the improved quality attributes while reversing the negative perception of consumers towards local rice. This could be a crucial step towards breaking the consumers' inertia against preference for imported rice brands.

The price differential between local and imported rice brands is lower than consumers' perceived quality differential. This negative price-quality differential gap is the reason for the persistence of consumers' inertia against preference and WTP for imported rice brands. Rice consumers in Nigeria compare price and quality differentials before making a choice between local and imported rice brands. There is therefore a need for synergy between public policy makers and marketing managers in designing and implementing import restriction and strategic marketing policies. This should be carried out in a flexible and complimentary manner in order to ensure sustenance of a wide price differential between local and imported rice brands while improving the quality and image of the local brands to narrow consumer's perception of the quality differential between these two sets of brands.

Economic theory assumes that consumers are rational and would always like to maximise utility. The finding of this study implies that, when a rational consumer is to make a choice between two or more brands of a product of almost similar quality attributes, preference or WTP for a particular

TABLE 6: Estimated consumers' inertia against preference for imported rice brands.

\begin{tabular}{lllll}
\hline Location & Price differential $\left(P_{\text {mdiff }}\right) \dagger$ & Quality differential (MWTP $) \neq$ & $\begin{array}{l}\text { Price-quality differentials gap } \\
\left(P_{\text {mdiff }}-\text { MWTP }\right) \S\end{array}$ & $\begin{array}{l}\text { Behaviour of household against preference } \\
\text { for imported rice brands }\end{array}$ \\
\hline AMAC & 3872 & 5855 & $-1,983$ & Inertia \\
Abaji & 3738 & 2608 & 1130 & No inertia \\
Kwali & 3771 & 3016 & 755 & No inertia \\
Gwagwalada & 3989 & 5315 & -1326 & Inertia \\
Kuje & 4195 & 5281 & -1086 & Inertia \\
Bwari & 3905 & 3771 & 134 & No inertia \\
Overall & 3911 & 4307 & -396 & Inertia \\
\hline
\end{tabular}

$\rightarrow, P$ denotes the price differential. It is the difference between the average retail market prices of local rice and the maximum price consumer is willing to pay for imported rice brands; $\$$ MWTP denotes the marginal WTP. It is the monetary value of consumer's WTP increased price as a reflection of additional importance attached to his or her preference; $\S$, Consumer inertia exists if $P_{\text {mdiff }}$ MWTP is negative; and positive otherwise.

Note: All the figures are monetary values expressed in Naira (1USD = $\# 120$ in 2003; 1USD $=\$ 200$ in 2014).

AMAC, Abuja Municipal Area Council; MWTP, marginal willingness to pay. 
brand is likely dependent on his or her perceived quality differential being higher than the market price differential. There is a need to integrate the role of price-quality differentials into the theoretical models of consumer behaviour for food products. This will help to provide useful insights into the understanding of consumers' choice behaviour towards two or more brands of a food product with almost similar quality attributes but of different price regimes.

\section{Acknowledgements Competing interests}

The authors declare that they have no financial or personal relationships that may have inappropriately influenced them in writing this article.

\section{Authors' contributions}

This article was conceived by U.O., who is responsible for the conception, data collection, analysis and writing up of the article, while L.B. provided technical advice and guidance at every stage.

\section{References}

Adeyeye, J.A., Navesero, E.P., Ariyo, O.J. \& Adeyeye, S.A., 2010, 'Consumer preference for rice consumption in Nigeria', Journal of Humanities, Social Science and Creativity Arts 5(1), 26-36.

AfricaRice, 2012, Boosting Africa's rice sector: A research for development strategy 2011-2020, Africa Rice Research Centre, Cotonou, Benin.

AGIS, 2014, AGIS deploys high resolution satellite imagery of the FCT, Abuja Geographic Information System, viewed from http://agis.fcta.gov.ng/

Akaeze, H.O., 2010, 'Consumer preference for imported rice in Nigeria - Perceived quality differences or habit persistence?', Unpublished M.Sc. thesis, Department of Agricultural, Food and Resource Economics, Michigan State University.

Akdeniz, B., Calantone, R.J. \& Voorhees, C.M., 2013, 'Effectiveness of marketing cues on consumer perceptions of quality: The moderating roles of brand reputation and third-party information', Psychology and Marketing 30(1), 76-89. https://doi. org $/ 10.1002 /$ mar.20590

Alfred, S.D.Y. \& Adekayode, A.B., 2014, 'Consumers' attitude towards local rice production in Ondo State, Nigeria', Journal of Agricultural Extension and Rural Development 6(7), 242-248. https://doi.org/10.5897/JAERD11.014

Ara, S., 2003, 'Consumers' WTP for multiple attributes of organic rice: A case study in the Philippines', paper presented at the 25th International Conference of Agricultural Economists, 16-22 August, Durban, South Africa, pp.1-15.

Bamidele, F.S., Abayomi, O.O.\& Esther, O.A., 2010, 'Economic analysis of rice consumption patterns in Nigeria', Journal of Agricultural, Science, and Technolog $12,1-11$

Ben-Akiva, M. \& Lerman, S., 1985, Discrete choice analysis, MIT Press, Cambridge.

Bennett, J.W., \& Blamey, R.K., 2001, The choice modelling approach to environmental valuation, Edward Elgar Publishing Inc., Northampton, MA.

Bernués, A., Olaizola, A. \& Corcoran, K., 2003, 'Extrinsic attributes of red meat as indicators of quality in Europe: An application for market segmentation', Food Quality and Preference 14, 265-276. https://doi.org/10.1016/S0950-3293(02) Quality

Bonti-Ankomah, S. \& Yiridoe, E.K., 2006, Organic and conventional food: A literature review of the economics of consumers' perceptions and preference, Final report, Organic Agriculture Centre of Canada. Nova Scotia Agricultural College, Truro, NS, Canada.

Bornemann, T. \& Homburg, C., 2011, 'Psychological distance and the dual role of price', Journal of Consumer Research 38(3), 490-504. https://doi.org/ $10.1086 / 659874$

Campbell, R., Schiff, H., Snodgrass, D., Neven, D., Downing, J. \& Sturza, D., 2009 Global food security response: West Africa rice value chain analysis, USAID microREPORT \# 161, United States Agency for International Development, Washington, DC.

Chern, W.S. \& Chang, C., 2009, 'Willingness to pay premium for foods produced in Taiwan and country of origin labeling: Results from auction experiment', pape presented at the 19th Annual World Symposium of the International Food and Agribusiness Management Association (IAMA), Budapest, Hungary, 20-21 June.

Chiliya, N., Herbst, G. \& Roberts-Lombard, M., 2009, 'The impact of marketing strategies on profitability of small grocery shops in South Africa townships', African Journal of Business Management 3(3), 70-79.
Enneking, U., 2004, Willingness-to-pay for safety improvement in the German meat sector: The case of the Q\&S label', European Review of Agricultural Economics 31, 205-223. https://doi.org/10.1093/erae/31.2.205

Erenstein, O., Lançon, F., Osiname, O. \& Kebbeh, M., 2003, 'Operationalising the strategic framework for rice sector revitalisation in Nigeria. Project report - The Nigerian economy in a competitive world: Constraints, opportunities and strategic choices. Abidjan: WARDA - The Africa Rice Centre. pp. ii-35.

Erhabor, P.O. \& Ojogho, O., 2011, 'Demand analysis for rice in Nigeria', Journal of Food Technology 9(2), 66-74. https://doi.org/10.3923/jftech.2011.66.74

Gerstner, E., 1985, 'Do higher prices signal higher quality?', Journal of Marketing Research 22(2), 209-215. https://doi.org/10.2307/3151366

Goldberg, I. \& Roosen, J., 2005, 'Measuring consumer willingness to pay for health risk reduction of salmonellosis and campylobacteriosis', paper presented the 11th Congress of EAAE, The Future of Rural Europe in the Global Agri-Food System, Denmark, 24-27 August, pp. 1-6.

Gonzalez, M.J. \& Loomis, B.J., 2006, 'Testing welfare measurement gains of combining stated and revealed preferences method using count data models', paper stated and revealed preferences method using count data models',
presented at AAEA Annual Meeting, Long Beach, CA, 23-26 July, pp.1-20.

Greene, P.E., 1974, 'On the design of choice experiments involving multifactor alternatives', Journal of Consumer Research 1(2), 61-68. https://doi.org/10.1086/ 208592

Greene, W.H., 2000, Econometric analysis, 4th edn., Prentice Hall, Upper Saddle River, NJ.

Gyimah-Brempong, K., Dorosh, P., Kuku, O., Pradesha, A. \& Ajibola, A., 2012, 'Informing Nigeria's agricultural transformation agenda with policy analysis and research evidence', paper presented at NSSP National Conference Held in Abuja, Nigeria, 13-14 November.

Haab, T. \& McConnell, K., 2002, Valuing environmental and natural resources: The econometrics of non-market valuation, Edward Elgar Publishing, Northampton, MA.

Hanemann, M., 1984, 'Welfare evaluations in contingent valuation experiments with discrete responses', American Journal of Agricultural Economics 67(3), 332-341. https://doi.org/10.2307/1240800

Hensher, D., Rose, J.\& Greene, W., 2005, Applied choice analysis: A primer, Cambridge University Press, Cambridge.

Johnson, M., Takeshima, H., Gyimah-Brempong, K. \& Kuku-Shittu, O., 2013, Policy options for accelerated growth and competitiveness of the domestic rice economy in Nigeria, IFPRI policy note 35, IFPRI, Washington, DC, viewed 30 February 2014 in Nigeria, IFPRI policy note 35, IFPRI, Washington, DC, viewed 30 February 2014,
from http://ebrary.ifpri.org/utils/getfile/collection/p15738coll2/id/127869/ from http://ebrary
filename/128080.pdf

Kassali, R., Kareem, R.O., Oluwasola, O. \& Ohaegbulam, O.M., 2010, 'Analysis of demand for rice in lle Ife, Osun State, Nigeria', Journal of Sustainable Development in Africa 12,2

Krutulyte, R., Ana, I., Costa, K. \& Grunert, G., 2009, 'A cross-cultural study of cereal food quality perception', Journal of Food Products Marketing 15(3), 304-323. https://doi.org/10.1080/10454440902966884

Lancaster, K.J., 1966, 'A new approach to consumer theory', Journal of Political Economy 74(2), 132-157. https://doi.org/10.1086/259131

Lançon, F. \& Benz, H.D., 2007, 'Rice imports in West Africa: Trade regimes and food policy formulation', poster prepared for the 106th Seminar of the European Association of Agricultural Economists, Montpellier, France, 25-27th October.

Lancon, F., Olaf, E., Akande, S.O., Titilola, S.O., Akpokodje, G. \& Ogundele, O.O., 2003, Imported rice retailing and purchasing in Nigeria: A survey. Project report - The Nigerian economy in a competitive world: Constraints, opportunities and strategic choices. Abidjan: WARDA - The Africa Rice Centre. pp. ii-14.

Latvala, T., 2010, 'Risk, information and trust in the food chain: Factors explaining consumer willingness to pay', International Journal Food System Dynamics 1(4), 295-304.

Maddala, G.S., 1993, The econometrics of panel data, Brookfield, Vt: Elgar, Aldershot, Hants, England.

McFadden, D., 1980, 'Econometric models for probabilistic choice among products', Journal of Business 53(3), 13-29.

McFadden, D., 1987, 'Regression-based specification tests for the multinomial logit model', Journal of Econometrics 34, 63-82. https://doi.org/10.1016/03044076(87)90067-4

Menard, S., 1995, Applied logistic regression analysis: Sage University series on quantitative applications in the social sciences, Sage, Thousand Oaks, CA.

Millock, K., Hansen, L.G., Wier, M. \& Anderson, L.M., 2002, 'Willingness to pay for organic foods: A comparison between survey and panel data from Denmark', paper presented at the 2nd World Congress of Environmental and Resource Economists held at Mariott Hotel in Monterey, CA. June 24-27, 2002. http://www. econweb.ucsd.edu/ carsonvs/papers/5065.pdf

Monroe, K.B., 2003, Pricing: Making profitable decisions, 3rd edn., Irwin, Burr Ridge, IL.NPC, 2013, National Population and Housing Census, National Population Commission, viewed 20 January 2016, from http://www.population.gov.ng/

PROPCOM, 2007, Demand and supply study on domestic and imported rice in Kano area. Monograph Series \# 22, July. UK Department for International Development, Abuja, Nigeria.

Quagrainie, K., 2006, 'IQF Catfish retail: A study of consumers' WTP', Internationa Food and Agribusiness Management Review 9, 2.

Raghubir, P. \& Corfman, K., 1999, 'When do price promotions affect pre-trial brand evaluations?', Journal of Marketing Research 36, 211-222. https://doi. org/10.2307/3152094 
Sahay, A. \& Sharma, N., 2010, 'Brand relationships and switching behaviour for highly used products in young consumers', Vikalpa 35(1), 15-30. https://doi. used products in young consum
org/10.1177/0256090920100102

Seck, P.A., Tollens, E., Wopereis, M.C.S., Diagne, A. \& Bamba, I., 2010, 'Rising trends and variability of rice prices: Threats and opportunities for sub-Saharan Africa', Food Policy 35(5), 403-411. https://doi.org/10.1016/j.foodpol.2010.05.003

Shiraia, M., 2010, 'Analyzing price premiums for foods in Japan: Measuring consumers' willingness to pay for quality-related attributes', Journal of Food Products Marketing 16(2), 184-198. https://doi.org/10.1080/104544409 03415113

Shiraia, M., 2015, 'Impact of high quality, low price appeal on consumer evaluations', Journal of Promotion Management 21(6), 776-797. https://doi.org/10.1080/104 96491.2015.1088922

Sonata, A. \& Rasa, G., 2010, 'Analyzing price-quality relationship using conjoint analysis', Economics and Management 15, S350-S358.

Thanasuta, K. \& Metharom, P., 2015, 'Influencing the willingness to pay for private labels: The role of branding', Asia-Pacific Journal of Business Administration 7(3) 197-215. https://doi.org/10.1108/APJBA-10-2014-0123
Travisi, C.M. \& Nijkamp, P., 2004, 'Are Italians willing to pay for agricultural environmental safety? A Stated choice approach', paper presented at 84th EAAE Economic Seminar on Food Safety in a Dynamic World, Ziest, Netherlands, 8-11 February.

Wallace, L.S., Blake, G.H., Parham, J.S.\& Baldridge, R.E., 2003, 'Development and content validation of family practice residency recruitment questionnaires', Family Medicine 35(7), 496-498.

Yamane, T., 1967, Statistics: An introductory analysis, 2nd edn., Harper and Row, New York.

Yue, C., Alfnes, F. \& Jensen, H.H., 2009, 'Discounting spotted apples: Investigating consumers' WTP to accept cosmetic damage in organic products', Journal of Agricultural and Applied Economics 14(1), 29-46.

Zeithaml, V.A., 1988, 'Consumer perceptions of price, quality, and value: A means-end model and synthesis of evidence', Journal of Marketing 52(July), 2-22.

Zeng, Y. \& Wei, X., 2005, 'Consumer's attitudes and perception toward green food in Beijing, concordant society and development of country', A selected paper of National Wide Agricultural Economist Annual Conference, China, Agriculture Press, November 21- 23, 2005, n.p. 